\title{
A new type of slumping-induced soft-sediment deformation structure: the envelope structure
}

\author{
Uk Hwan Byun ${ }^{1,2}$, A.J. (Tom) van Loon², Yi Kyun Kwon³, Kyoungtae Ko ${ }^{1 *}$ \\ ${ }^{1}$ Geology Division, Korea Institute of Geoscience and Mineral Resources (KIGAM), Daejeon 34132, South Korea; \\ e-mail: buh@kigam.re.kr \\ ${ }^{2}$ College of Earth Science and Engineering, Shandong University of Science and Technology, Qingdao 266590, \\ Shandong, China; e-mail: Geocom.VanLoon@gmail.com; tom.van.loon@wxs.nl \\ ${ }^{3}$ Department of Geoenvironmental Sciences, Kongju National University, Kongju 314-701, South Korea; \\ e-mail: kyk70@kongju.ac.kr \\ *corresponding author, e-mail: kkt@kigam.re.kr
}

\begin{abstract}
The sediments of the Cretaceous Gyeokpori Formation in south-western South Korea accumulated in a lake in which mainly siliciclastic rocks were deposited, with some interbedded volcaniclastics. The nearby volcanic activity resulted in unstable lake margins inducing a dominance of gravity-flow deposits. The high sedimentation rate facilitated soft-sediment deformation on the sloping margin. The deposition of numerous gravity-flow deposits resulted in a vertically heterolithic stratification. The slumps are composed of different lithologies, which is expressed in different types of deformation due to the difference in cohesion between sandy and mussy layers within the slumps. Coarser-grained (cohesionless) slumps tend to show more chaotic deformation of their lamination or layering. The difference in slumping behaviour of the cohesive and non-cohesive examples is explained and modelled.

A unique soft-sediment deformation structure is recognized. This structure has not been described before, and we call it 'envelope structure'. It consists of a conglomerate mass that has become entirely embedded in fine-grained sediment because slope failure took place and the fine-grained material slumped down with the conglomerate 'at its back'. The cohesive laminated mudstone formed locally slump folds that embedded the non-cohesive overlying conglomerate unit, possibly partly due to the bulldozing effect of the latter. This structure presumably can develop when the density contrast with the underlying and overlying deposits is exceptionally high. The envelope structure should be regarded as a special - and rare - type of a slumping-induced deformation structure.
\end{abstract}

Key words: Gyeokpori Formation, Cretaceous, lacustrine environment, slumping, conglomerate

\section{Introduction}

Soft-sediment deformation structures (SSDS) occur in many forms and are known to be formed by a wide variety of processes (see Moretti et al., 2016). These range from earthquake-induced seismic waves (e.g., Sims, 1973, 1975; Hempton \& Dewey, 1983; Alfaro et al., 1997; Rodríguez-Pascua et al., 2000; Taşgın \& Türkmen, 2009; Gibert et al., 2011; Taşgın et al., 2011) to tectonically induced faulting (Van Loon, 2002; Neuwerth et al., 2006) to the impact of meteorites (Wynn, 1998; Raukas et al., 2001) and tension (Yang \& Van Loon, 2016), to overloading (Tipper et al., 2003; Moretti \& Sabato, 2007), to compaction (Denhandschutter, 2005) to slope processes (Talling et al., 2004) to biological activity by animals (Uchman et al., 2008) and plants (Rygel et al., 2004) to glacial push (Aber \& Ber, 2007) or melting (Gruszka \& Van Loon, 
2011) to changes in temperature (Williams et al., 2008), to slurry transport (Yang et al., 2016) to many more. A good overview of the various SSDS-producing processes is presented by Van Loon (2009). All these studies emphasize that the deformational processes cannot always be reconstructed with certainty, because differences in sediment characteristics or depositional processes can lead to entirely different SSDS. There are, however, also studies that describe and analyse SSDS of which the genetic process can be reconstructed with great certainty, because the process and the resulting structures have been observed in modern times, or because the context is so specific that other origins can be excluded.

Particularly when rapid sedimentation takes place subaqueously, and even more when the deposition takes place on a slope, SSDS are frequently formed due to the instability of the sedimentary succession. Both conditions were present when the SSDS under study here originated.

The structure under study was found in the Cretaceous Gyeokpori Formation, which is ex- posed along the western coast of South Korea. The formation consists of lacustrine sediments that accumulated on the slope of a subaqueous fan-delta system, a position that is commonly considered most suitable to inducing and preserving SSDS (Gibert et al., 2005; Moretti \& Sabato, 2007; Tanner \& Lucas, 2007; Gladkov et al., 2016; Jiang et al., 2016; Ko et al., 2017). Indeed, the formation contains numerous slump-related SSDS (Martinsen, 1989; Porębski \& Steel, 2003) in addition to the one under study.

\section{Geological setting}

The eastern margin of the East Asian continent underwent left-lateral wrench tectonics during the Cretaceous due to oblique subduction of the Izanagi Plate (e.g., Chough \& Sohn, 2010). During this subduction, the Korean Peninsula was subjected to both left-lateral tectonics-generated faulting and continental arc volcanism, which formed numer-
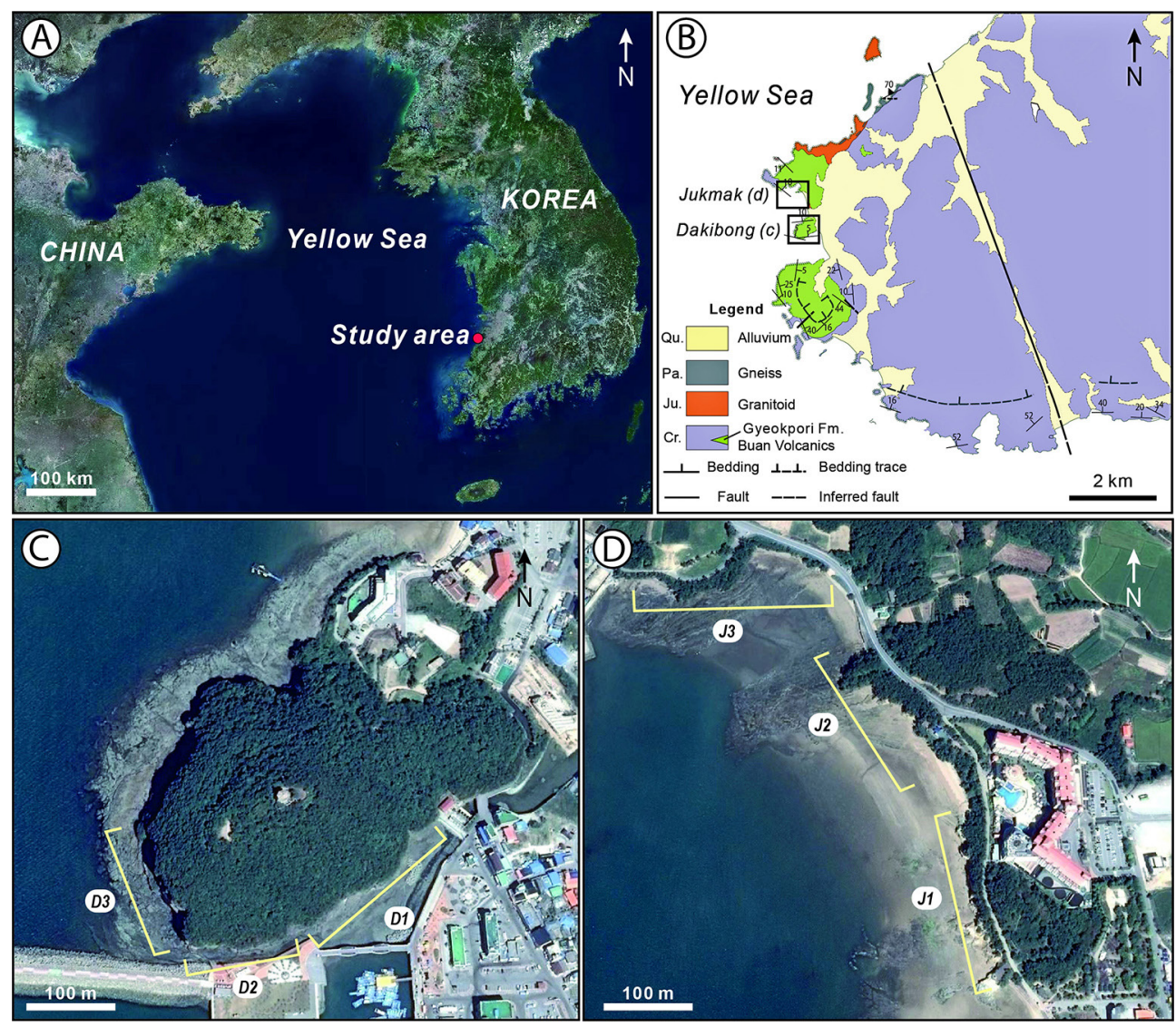

Fig. 1. Geological and geographical setting of the study area. A - Location in south-western South Korea; B - Schematic geological map of the western margin of the mostly volcanic area of Byeonsanbando National Park (modified after Koh et al., 2013); C, D - Aerial maps (from http:/ / map.google.com) showing the locations of the sections near (C) Dakibong and (D) Jukmak. Sections J1-J3 and D1-D3 indicate the locations of the successions shown in Figure 2 with the same codes 
ous non-marine sedimentary basins of different sizes (Chough, 2013). One of them was the Gyeokpori Basin, located on the south-western shore of the Korean Peninsula (Fig. 1). It was a lacustrine strike-slip basin resulting from left-lateral strikeslip displacement of the basin-bounding faults that trend NE-SW (Kim et al., 2003). According to recent field mapping in the area, the basin is located west of a large volcanic body covering an area about $20 \mathrm{~km}$ long and $10 \mathrm{~km}$ wide. The basin became filled with a succession now known as the Gyeokpori Formation.

\subsection{Lithology and facies}

The Gyeokpori Formation, which is about $290 \mathrm{~m}$ thick, is composed of conglomerates with clasts of various sizes, gravelly sandstones, mudstones, and abundant volcaniclastic deposits (Fig. 2). Most of these are gravity-flow deposits formed by debris flows and turbidity currents (Kim et al., 2003). Ten distinct sedimentary facies are distinguished based on their textures and sedimentary structures (see Table 1 for details and environmental interpretations; Fig. 2). The facies are here grouped into five

Table 1. Description and interpretation of the ten sedimentary facies defined in the Gyeokpori Formation

\begin{tabular}{|c|c|c|}
\hline Facies & Description & Interpretation \\
\hline $\begin{array}{l}\text { sandstones with } \\
\text { intraclasts (Si) }\end{array}$ & $\begin{array}{l}\text { well-sorted fine- to very coarse-grained sandstones with common } \\
\text { outsized mudstone clasts, up to boulder size, occasionally de- } \\
\text { formed; common mudstone chips; sharp and flat bases; massive, } \\
\text { normally graded and inversely graded or laminated; sometimes } \\
\text { lenticular }(5-20 \mathrm{~cm}) \text {, intercalated in Ml }\end{array}$ & $\begin{array}{l}\text { sediment gravity flows } \\
\text { (Kim et al., 2003) with } \\
\text { synsedimentary SSDS }\end{array}$ \\
\hline $\begin{array}{l}\text { homogene } \\
\text { mudstone }\end{array}$ & structureless; dark grey to black; non-calcareous; some trace fossils & $\begin{array}{l}\text { settling from suspension } \\
\text { under low-energy condi- } \\
\text { tions }\end{array}$ \\
\hline $\begin{array}{l}\text { laminated } \\
\text { mudstones } \\
(\mathrm{Ml})\end{array}$ & $\begin{array}{l}\text { mostly siltstones, also sandy siltstones and mudstones; finely lami- } \\
\text { nated; light grey to black; occasional ripple marks; abundant plant } \\
\text { debris; locally outsized pebbles; commonly folded or convoluted }\end{array}$ & $\begin{array}{l}\text { fine-grained turbidites (cf. } \\
\text { Bouma, 1962; Kim et al., } \\
\text { 2003) }\end{array}$ \\
\hline $\begin{array}{l}\text { clast-supported } \\
\text { conglomerates (Cc) }\end{array}$ & $\begin{array}{l}\text { clast-supported conglomerates }(1-1.5 \mathrm{~m} \text { thick) containing occa- } \\
\text { sionally deformed mudstone clasts within a coarse to very coarse } \\
\text { sandy matrix; most clasts }<10 \mathrm{~cm} \text {; reverse grading in poorly sorted } \\
\text { lower part; erosional lower boundaries with gutter casts; crudely } \\
\text { stratified; occasionally massive sandstones in top part; intraclasts } \\
\text { are generally angular and mostly tabular; locally conglomerates } \\
\text { are incised by channels with normally graded conglomerates or } \\
\text { medium-grained sandstones }\end{array}$ & $\begin{array}{l}\text { cohesionless debris flows } \\
\text { (cf. Lowe, 1982; Kim et al., } \\
\text { 2003) }\end{array}$ \\
\hline $\begin{array}{l}\text { matrix-supported } \\
\text { conglomerates } \\
(\mathrm{Cm})\end{array}$ & $\begin{array}{l}\text { matrix-supported conglomerate ( } 1-5 \mathrm{~m} \text { thick) with mudstone clasts } \\
\text { (occasionally deformed mudstone blocks) packed in coarse to very } \\
\text { coarse sandy matrix; poorly sorted; intraclasts are mostly angular } \\
\text { and tabular. Visible dimensions of clasts are up to } 0.2 \mathrm{~m} \text { high and } \\
0.5 \mathrm{~m} \text { long }\end{array}$ & $\begin{array}{l}\text { hyperconcentrated density } \\
\text { flows (cf. Mulder and } \\
\text { Alexander, 2001) }\end{array}$ \\
\hline $\begin{array}{l}\text { lenticular con- } \\
\text { glomerates to } \\
\text { gravelly sand- } \\
\text { stones (Gl) }\end{array}$ & $\begin{array}{l}\text { lateral extent of few dm to tens of } \mathrm{m} \text {; thickness few } \mathrm{dm} \text { to } \mathrm{m} \text {; suban- } \\
\text { gular to rounded clasts; common large boulders ( }>2 \mathrm{~m} \text { ); lobate units: } \\
\text { tightly interlocked large clasts; matrix of fine sand to silt; tabular or } \\
\text { trough cross-stratification; single or vertically stacked units }\end{array}$ & $\begin{array}{l}\text { high-discharge flash floods } \\
\text { (cf. Allen, 1982; Kim et al., } \\
\text { 2003) }\end{array}$ \\
\hline $\begin{array}{l}\text { bedded sandstones } \\
\text { (Sb) }\end{array}$ & $\begin{array}{l}\text { sometimes massive; laterally continuous; mostly medium-sized } \\
\text { sandstone; rounded pebbles; occasional quartz aggregates; crudely } \\
\text { stratified; normally graded at top; inversely graded parts; erosion- } \\
\text { al boundaries; low-angle cross-stratification; folded; sometimes } \\
\text { chaotic }\end{array}$ & $\begin{array}{l}\text { concentrated density flows } \\
\text { (cf. Mulder and Alexan- } \\
\text { der, 2001) }\end{array}$ \\
\hline $\begin{array}{l}\text { graded sandstone/ } \\
\text { mudstone layers } \\
(\mathrm{SMc})\end{array}$ & $\begin{array}{l}\text { sandstones upward grading into mudstones; occasionally inversely } \\
\text { graded in bottom part; sandstone units weakly laminated; well } \\
\text { sorted; crudely laminated mudstones }\end{array}$ & $\begin{array}{l}\text { turbidity currents (cf. } \\
\text { Bouma, 1962) }\end{array}$ \\
\hline $\begin{array}{l}\text { bedded breccias } \\
(\mathrm{Bb})\end{array}$ & $\begin{array}{l}\text { thick to very thick bedded (up to }>2 \text { m); mostly subangular to } \\
\text { angular clasts; tabular beds or hummocky beds; clast-supported; } \\
\text { coarse to very coarse sand-sized matrix }\end{array}$ & $\begin{array}{l}\text { cohesionless debris flows } \\
\text { and rock falls (cf. Nemec } \\
\text { and Steel, 1984) }\end{array}$ \\
\hline tuffs $(\mathrm{T})$ & $\begin{array}{l}\text { fine-grained blueish grey or greenish grey volcanic ash with some } \\
\text { lapilli; mostly dm thick; mostly homogeneous with occasionally } \\
\text { slight grading; laterally well correlatable }\end{array}$ & ash fall (Kim et al., 2003) \\
\hline
\end{tabular}




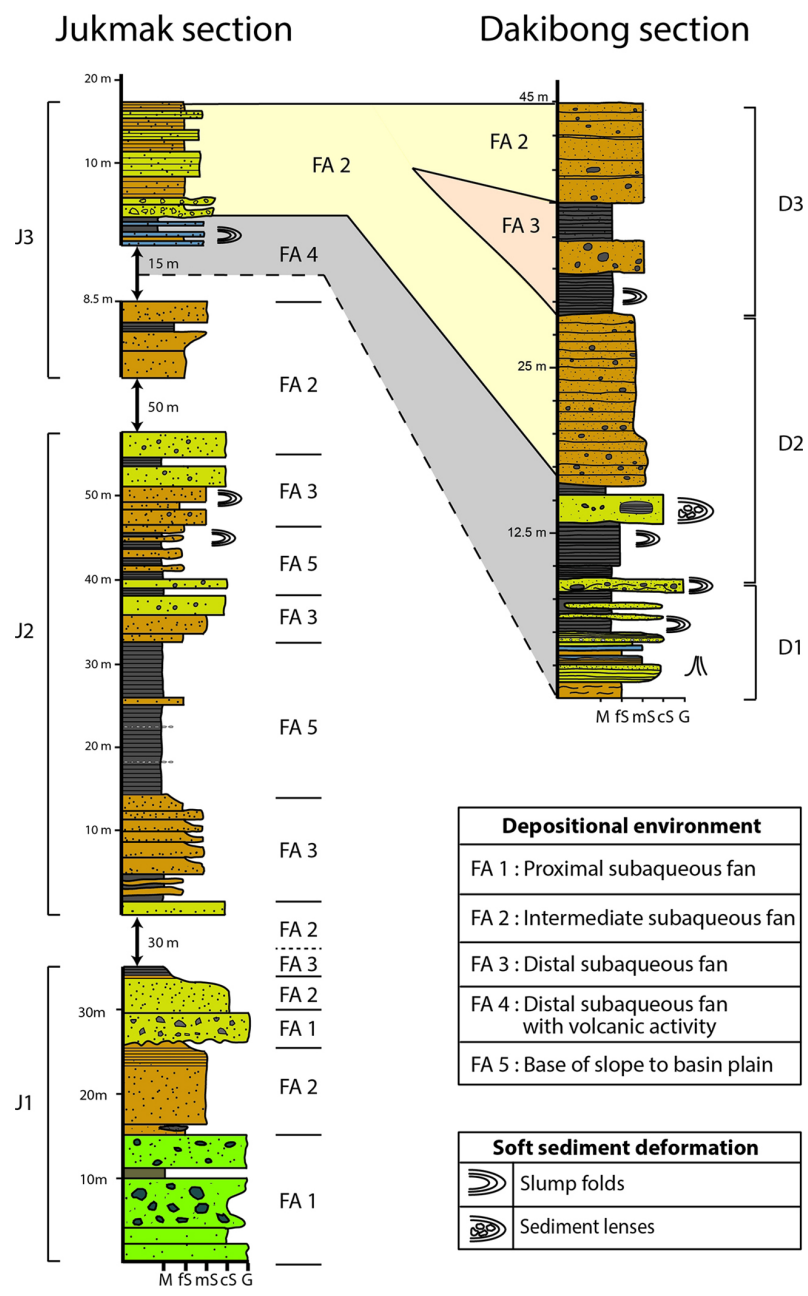

Fig. 2. Composite lithological logs of the Jukmak and Dakibong sections (see Fig. 1 for locations). FA = facies association; $\mathrm{M}=$ mud; $\mathrm{fS}=$ fine sand; $\mathrm{mS}=$ medium sand; $\mathrm{cS}=$ coarse sand; $\mathrm{G}=$ gravel associations (Table 2), four of which represent subaqueous fan systems, and one the basin plain (Kim et al., 1995, 2003).

A minor part of the sediments was deposited on the steep basin slope, but most accumulated on the basin plain in front of lacustrine deltas (Kim et al., 2003). This setting explains the occurrence of slumps, some of which are, in addition to the more detailed analysis of the envelope structure dealt with in Section 3, described in Section 4.

\subsection{Sections studied}

The SSDS in the Gyeokpori Formation were studied in two sections, located near the villages of Jukmak and Dakibong (Fig. 2).The sediments are exposed in coastal cliffs and on wave-cut terraces along the western coast of Byeonsanbando National Park (Kim et al., 1995, 2003). Most of the formation is present in the Jukmak section, whereas only the upper part is present in the Dakibong section (Kim et al., 2003). SSDS occur in the middle and upper parts of the formation. The middle part of the formation is mainly composed of an alternation of mudstones and sandstones with slump folds, whereas the upper part is mainly composed of sandstones and conglomerates with intercalated mudstones with some envelope structures.

Palaeocurrent directions obtained from the geometry and dip direction of delta lobes, bed geometry, and sedimentary structures such as flute casts, current ripples, and gravel clusters, indicate that the delta on the southern margin of the basin prograded toward the north-northwest, while the delta

Table 2. Description and environmental interpretation of the five facies associations in the Gyeokpori Formation.

\begin{tabular}{|c|c|c|c|c|}
\hline Facies association & Facies & Description & \multicolumn{2}{|c|}{ Interpretation } \\
\hline FA 1 & $\mathrm{Cc}, \mathrm{Gl}, \mathrm{Bb}, \mathrm{Sb}$ & $\begin{array}{l}\text { mainly conglomerate beds, some } \\
\text { coarse-grained sandstones; chan- } \\
\text { nelized sandstone beds }\end{array}$ & $\begin{array}{l}\text { proximal subaque- } \\
\text { ous fan }\end{array}$ & \multirow{4}{*}{$\begin{array}{l}\text { lacustrine fan (cf. } \\
\text { Nemec and Steel, } \\
\text { 1984; Kim et al., } \\
\text { 2003) }\end{array}$} \\
\hline FA 2 & $\mathrm{Sb}, \mathrm{Ml}, \mathrm{Gl}$ & $\begin{array}{l}\text { mainly coarse-grained sand- } \\
\text { stones with upward grading; } \\
\text { some sandstone bodies form } \\
\text { lobes }\end{array}$ & $\begin{array}{l}\text { intermediate sub- } \\
\text { aqueous fan }\end{array}$ & \\
\hline FA 3 & $\begin{array}{l}\mathrm{Sb}, \mathrm{Si}, \mathrm{Ml}, \mathrm{Cc} \\
\mathrm{Cm}, \mathrm{SMc}\end{array}$ & $\begin{array}{l}\text { mainly sandstones ( } \mathrm{Sb} \text { and } \mathrm{Si} \text {, } \\
\text { with upward grading; deformed } \\
\text { sandstone layers }\end{array}$ & $\begin{array}{l}\text { distal subaqueous } \\
\text { fan }\end{array}$ & \\
\hline FA 4 & $\begin{array}{l}\mathrm{Sb}, \mathrm{Si}, \mathrm{Ml}, \mathrm{Cc} \\
\mathrm{Cm}, \mathrm{SMc}, \mathrm{T}\end{array}$ & $\begin{array}{l}\text { similar to FA } 3 \text {, but with in- } \\
\text { tercalated tuff beds; deformed } \\
\text { sandstone layers }\end{array}$ & $\begin{array}{l}\text { distal subaqueous } \\
\text { fan accumulated dur- } \\
\text { ing volcanic activity }\end{array}$ & \\
\hline FA 5 & $\mathrm{Ml}, \mathrm{Mh}, \mathrm{Si}, \mathrm{Sb}$ & $\begin{array}{l}\text { thick mudstones (Ml and } \mathrm{Mh} \text { ) } \\
\text { with some intercalated sand- } \\
\text { stones ( } \mathrm{Si} \text { and } \mathrm{Sb} \text { ); numerous } \\
\text { folded mass-flow deposits }\end{array}$ & $\begin{array}{l}\text { toe of slope to basin pl } \\
\text { Chough, 1992; Kim et }\end{array}$ & $\begin{array}{l}\text { lain (cf. Chun and } \\
\text { al., 2003) }\end{array}$ \\
\hline
\end{tabular}


on the northern basin margin prograded toward the south-southwest (Kim et al., 2003). It can thus be deduced that the depocentre of the basin was located in the western part of the basin, and the bottom of the basin was gently inclined into the same direction (Kim et al., 2003).

\section{The envelope structure}

A clast-supported conglomerate (facies Cc; see Table 1) in the upper part of the formation in the Dakibong section contains a bed (Fig. 3) with the distinctive deformation structure that we call 'envelope structure', and that, as far as we are aware, never has been described before.

\subsection{Description}

The envelope structure consists of a conglomerate lens (facies $\mathrm{Cc}$ ) embedded in laminated mudstone. The conglomerate has a dark grey mud- to sand-sized matrix. Most of the grain boundaries are sharp, but the boundaries between successive layers are not easily discernible in the matrix. It is clear, however, that the thickness of the deformed conglomerate bed (facies $\mathrm{Cc}$ ) under study here varies strongly within lateral distances of only $0.2-1 \mathrm{~m}$. The degree of deformation is highest where the layer is thickest.

The deformed conglomerate rests on a bed belonging to laminated mudstone (facies Ml, Table 1) and is also overlain by a similar bed of facies Ml. This overlying bed is connected with the underly- ing bed through a fold structure that surrounds the conglomerate (facies $\mathrm{Cc}$ ) at all sides so that the conglomerate shows a lens shape (Fig. 4). At the bottom of the conglomerate lens, load casts are present. The thickest part of the conglomerate lens is $1 \mathrm{~m}$ thick and its length is about $3 \mathrm{~m}$. Disorganized matrix-supported conglomerates (facies $\mathrm{Cm}$ ) are present at the same stratigraphic level (Figs. 3 and 4) and seem to be equivalent to the conglomerate lens (facies $\mathrm{Cc}$ ). These conglomerates are matrix-supported and locally contain cobble- to boulder-sized clasts (visible dimensions are up to $0.2 \mathrm{~m}$ high and $0.5 \mathrm{~m}$ long) of laminated mudstone (facies M1), some of which are folded.

The clasts of the conglomerate lens (facies Cc) have various compositions including mainly quartzites, sandstones and volcanics. The clasts larger than $20 \mathrm{~cm}$ are relatively rounded but smaller clasts are angular to sub-angular. In contrast to the conglomerate lens, boulder-sized clasts are rare in the nearby conglomerate layer, but the clasts in this layer are also polymict. They consist of mainly quartzites, sandstones, and volcanics. There is no notable orientation or concentration of clasts in the conglomerate lens. However, some grading seems to be present where the lens pinches out (Fig. 4).

The lower boundary of the conglomerate lens is non-erosional, but the nearby conglomerate layer erodes the underlying facies Ml bed (Fig. 3). Where the conglomerate (facies $\mathrm{Cc}$ ) is thickest, the underlying bed (facies Ml) is thin. This bed is composed mainly of laminated mudstones and laminated siltstones with a few intercalated fine-grained sandstones (facies SMc).

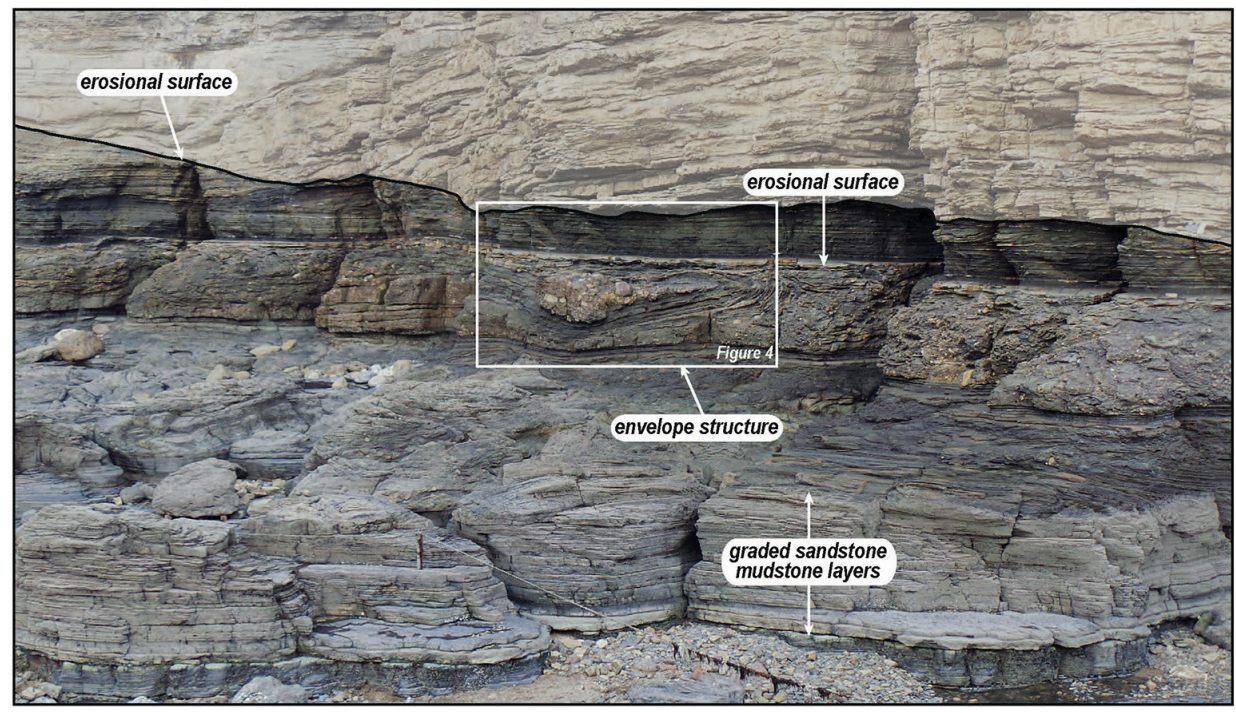

Fig. 3. Outcrop in the Dakibong section, representing the upper part of the Gyeokpori Formation, with the position of the envelope structure 
Considering the large number of slumps and the occasional presence of gravelly layers, it is not remarkable that comparable envelope structures are present. The best exposure of the envelope structures is in a steep coastal cliff; these are, however, not accessible without difficulty. The conglomerate lens is embedded in predominantly fine-grained material of a slump (Fig. 5). The lens is some $40 \mathrm{~cm}$ high and about half a metre long. The largest clast is almost $30 \mathrm{~cm}$ long, and its longest axis is oriented vertically. This suggests a final position after a last rotational movement of the slumping mass of predominantly fine-grained material (facies $\mathrm{Ml}$ ).

\subsection{Interpretation}

The envelope structures were formed when gravelly to pebbly sediments were deposited on top of mud deposits in the proximal or middle part of the basin (Fig. 6A). This resulted in instability, which caused flow of the underlying cohesive finegrained sediments (facies $\mathrm{Ml}$ ) and in slumping of the non-cohesive coarse-grained sediments (facies $\mathrm{Cc}$ ) at the same time. The simultaneous down-slope flow of both sediment types caused different types of deformation (Fig. 6B). The cohesive laminated mudstone (facies $\mathrm{Ml}$ ) formed locally slump folds that embedded the non-cohesive overlying conglomerate unit (facies Cc) (Fig. 6C), possibly partly due to the bulldozer-like effect that the coarsegrained lens exerted on the folded fine-grained material in front of it.

Considering thickness variations of the underlying mudstone unit (facies $\mathrm{Ml}$ ) and the relatively large clasts in the conglomerate unit (facies $\mathrm{Cc}$ ) (Fig. 6C), the conglomerate may have resulted in an instable density gradient. This will have caused loading, which resulted in the thinning of the mud under the conglomerate lens. This may have facilitated the local slumping and the bulldozing effect in combination with the unequal loading.
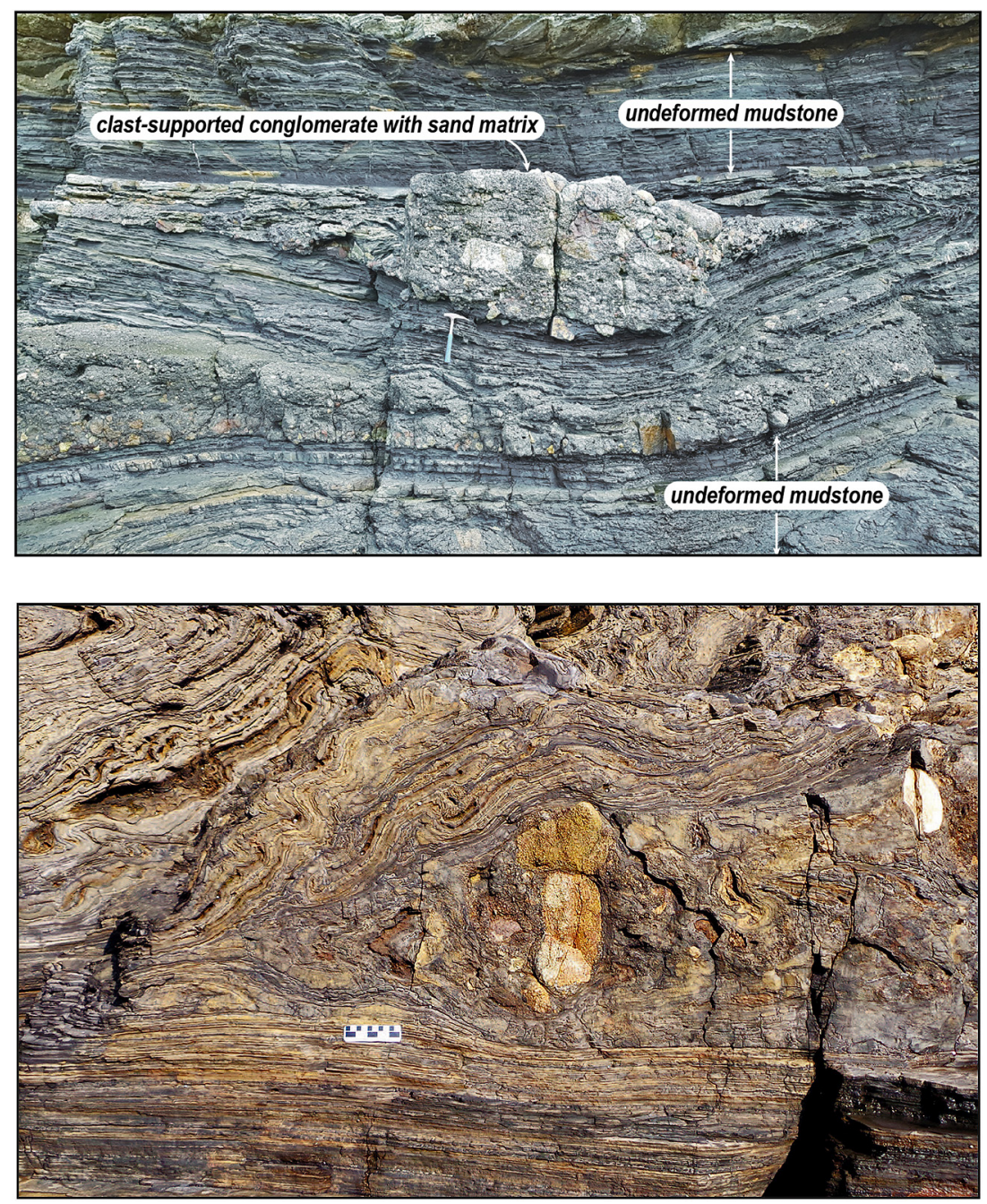

Fig. 4. Envelope structure, showing a lens of clast-supported conglomerate (facies Cc) with a sandy matrix, surrounded like an envelope by deformed mudstones (facies $\mathrm{Ml}$ ) (note the folds to the right of the lens)

Fig. 5. Second example of an envelope structure (see text for details). For location, see Figure 2 

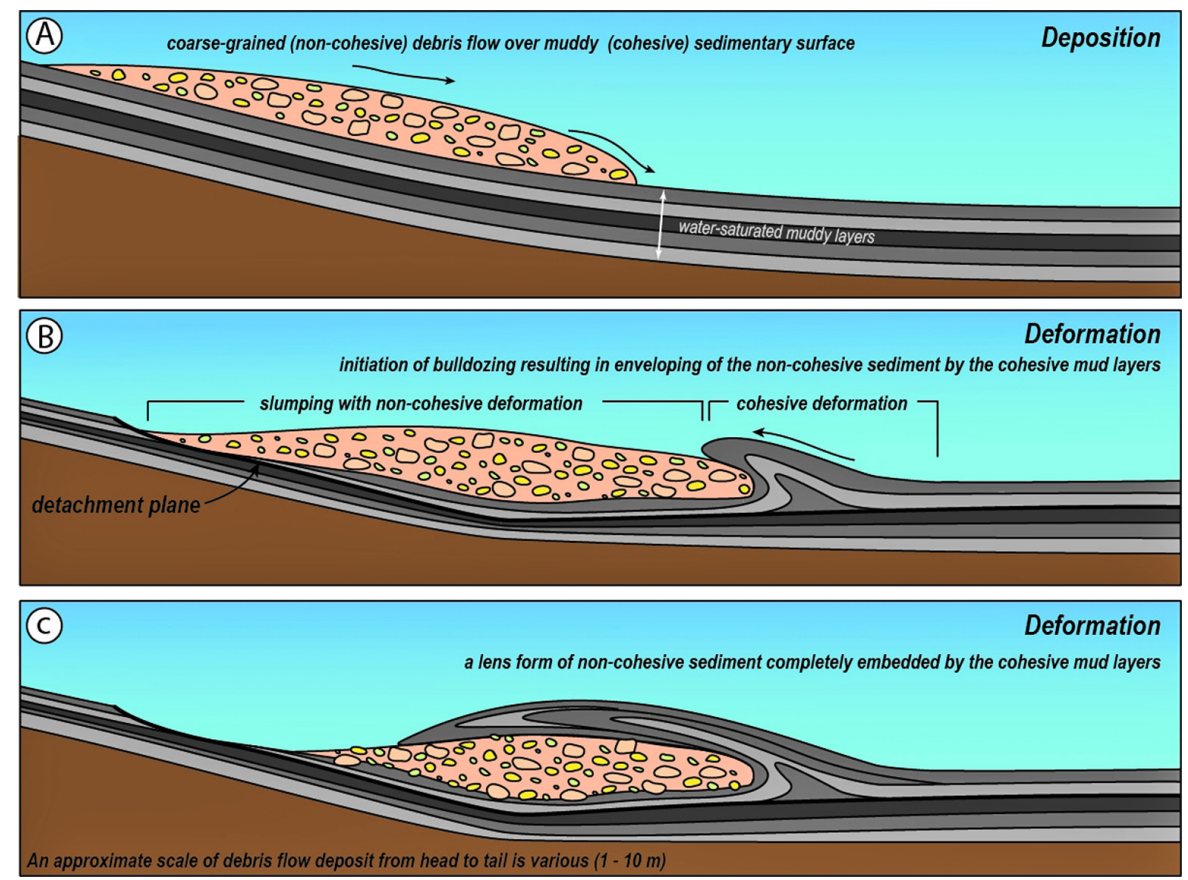

Fig. 6. Schematic 2D model for the development of an envelope structure. A - Deposition of a coarse-grained gravity flow on top of finer-grained sediments on a slope; B - Ongoing slumping of the coarse-grained sediment, resulting in bulldozing of the fine-grained sediments in front; C - Final enveloping of coarse-grained sediments within finer sediments

\section{Other slumps in the Gyeokpori Formation}

In addition to the envelope structure, slump structures (Fig. 2) are common in the formation (see also Ko et al., 2015). We consider it useful to pay attention to these slumps here because they provide insight into the general conditions under which the various deformation processes took place.

\subsection{Description}

Slump folds are frequently present in the laminated mudstones of facies $\mathrm{Ml}$ and SMc. They consist of up to $1 \mathrm{~m}$ thick sets of layers with variable thickness (Fig. 7). The complex internal structures in folds suggest an at least partial rotational movement during the downslope flow (Fig. 8). The grain-size distributions vary for the layers involved. The individual layers within the deformed set of layers in facies in $\mathrm{Ml}$ and SMc can be sand-dominated (Fig. 9), mud-dominated (Fig. 10), or consist of sand and mud in roughly similar quantities (Fig. 11).

Primary features, such as planar bedding and lamination, are well preserved in the mud-dominated fold structures (Fig. 8). These are locally associated with low-angle faults of both reverse and normal type (Fig. 12). The axes of the folds show a quite low-angle dip (Fig. 11), i.e., they are sub-parallel or parallel to the bedding. The more abundant the sandy sediments are, the more severe the deformation tends to be, resulting in undulations or sometimes disrupted laminations. The folds occasionally also contain rock fragments that interrupt the original lamination. Some of these fold structures are accompanied by water-escape structures in the uppermost part of the layers.

\subsection{Interpretation}

The preservation of the primary structures indicates that the deformation must be ascribed to liquefaction, not fluidization. Considering that facies analysis indicates deposition on the marginal slope of the basin and taking into account the orientation of the fold axes and the rotational character of the deformed material, the folding must have taken place during slumping of the layered sediments. The main process resulting in soft-sediment slumping is commonly thought to be steepening of the depositional surface either by tilting (Mills, 1983; Owen, 1996), or by rapid sediment accumulation (Yang et al., 2017; Zhao et al., 2018). The most commonly invoked trigger mechanism for the initiation of slumping is consequently a "metastable" slope 


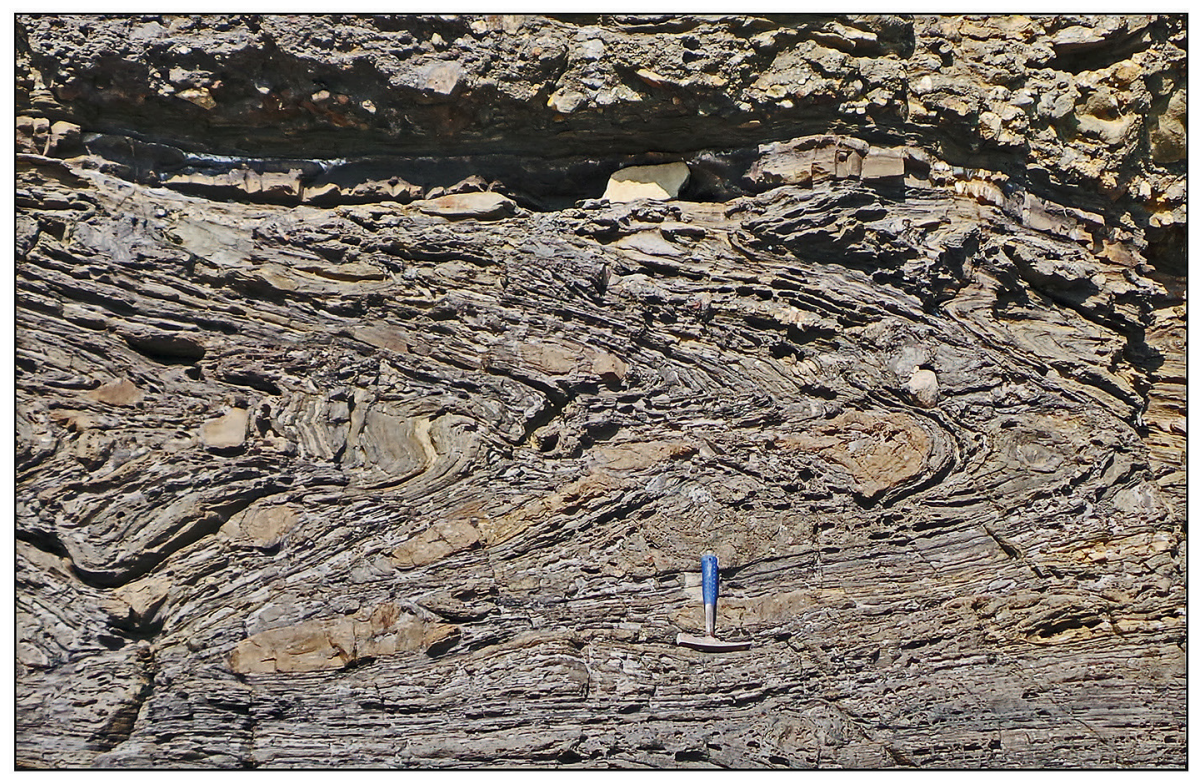

Fig. 7. Most slumps have thicknesses of more than a metre and are built of sandy and muddy turbidites (facies SMc and $\mathrm{Ml}$ ) of different thicknesses and cohesion, resulting in different folding behaviour. Sandy layers locally lose their original structures. Location: lower part of D2 in Figure 2

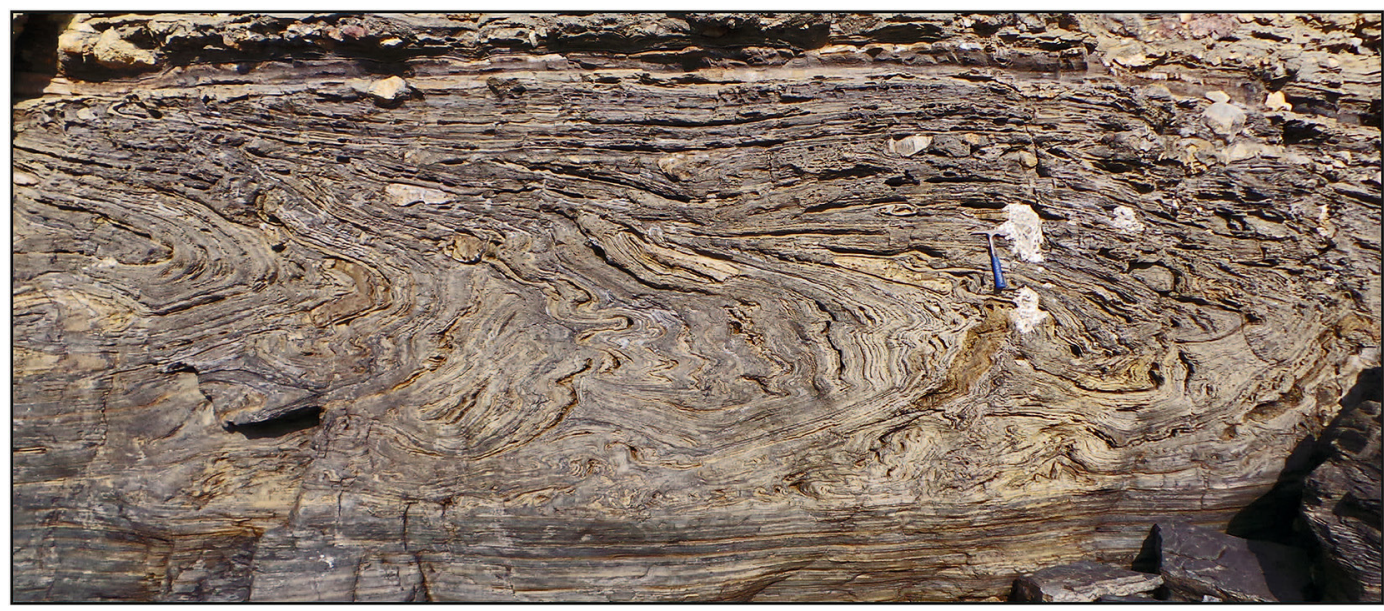

Fig. 8. The rotational movement of the slump heads caused space problems that commonly led to complex deformations. Same stratigraphic level as Figure 7

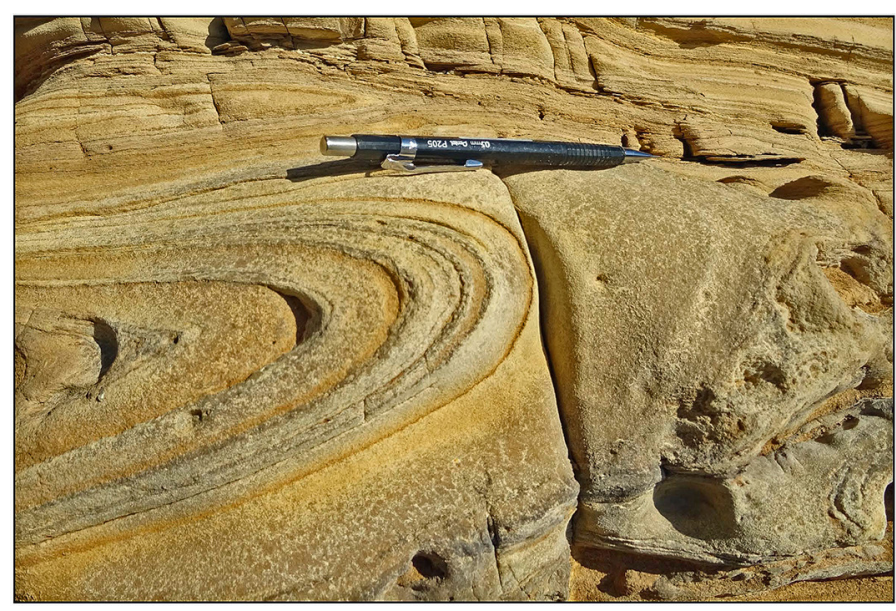

Fig. 9. Purely sandy slumps (facies $\mathrm{Sb}$ ) are relatively rare, but do occur. The deformation within the slumps is commonly relatively simple. Location: middle part of $\mathrm{J} 2$ in the Jukmak section 


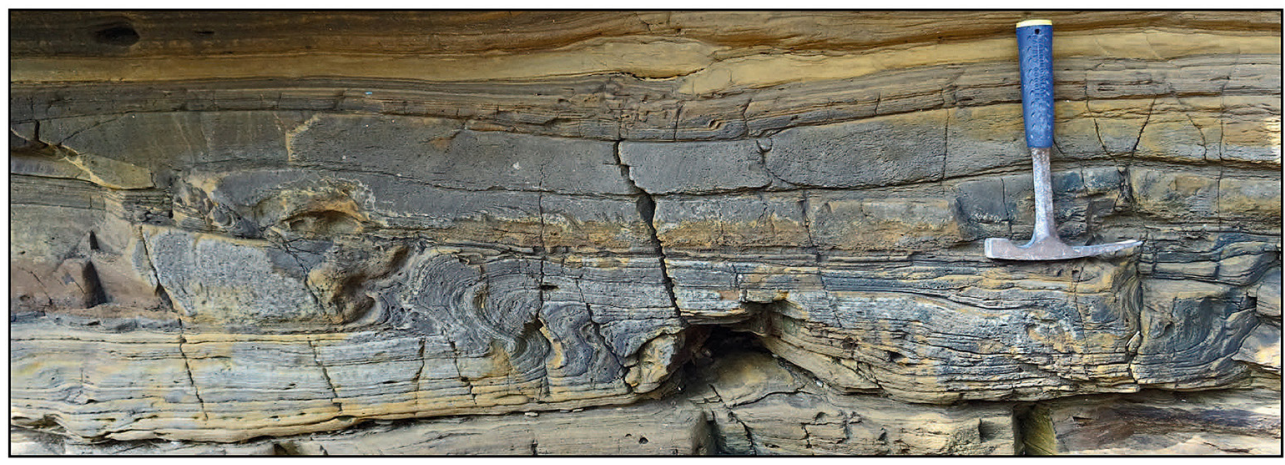

Fig. 10. Slumps consist exclusively of finely laminated mudstone (facies Ml) that was easily folded, commonly but not always resulting in sharp fold bends of relatively small dimensions. Location: middle part of D1 in the Dakibong section

condition, although seismic shocks (due to whatever event) are also being recognized as possible triggers (Allen, 1982).

Considering the mud content of facies $\mathrm{Ml}$, these sediments must have behaved as cohesive hydroplastic material, which explains the resulting deformations (Fig. 13) (cf. Alsop et al., 2016). The pore pressure was likely less than the cohesive strength of the fine-grained sediment, so that the primary structures were preserved during deformation (Fig. 13A-B). Gravity, acting on the sediments that had accumulated on the slope of the basin margin, provided the shear force that was needed to deform the unconsolidated mud layers.

Where a sandy layer (facies SMc) was present between mud layers, non-cohesive deformation in the sand must have occurred at a higher pore pressure (Fig. 13C-F). The deformation style was consequently different for the cohesive (Fig. 14) and non-cohesive sediments (Figs. 15, 16), explaining the differences in deformation type that originated during downslope movement of the unconsolidated sediment layers. The cohesive sediments (muds)

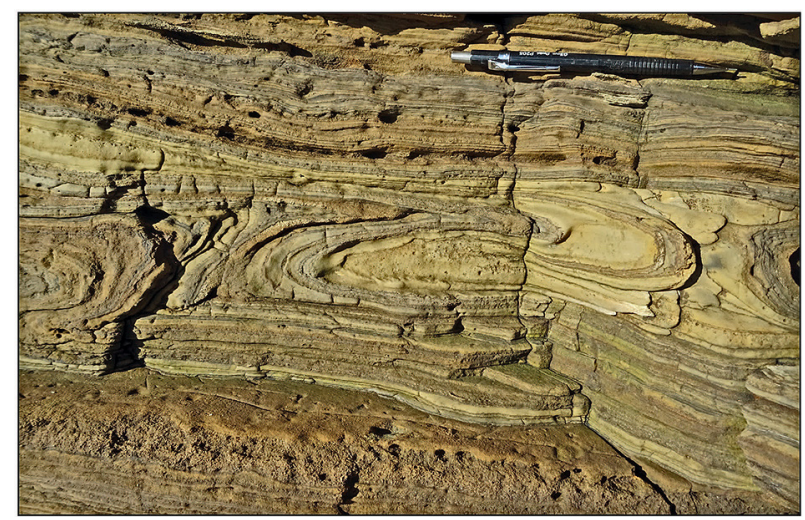

Fig. 11. Slumps consisting of both sandy and muddy layers (facies SMc) show, due to the differences in cohesion, both ductile and brittle deformation, expressed as folds (ductile) and faults sand other types of disruption (brittle). Location: upper part of J2 in the Jukmak section

were deformed while largely maintaining their initial characteristics, but the non-cohesive sediments were deformed into undulating beds. Sometimes the primary structures became even destroyed. Un-

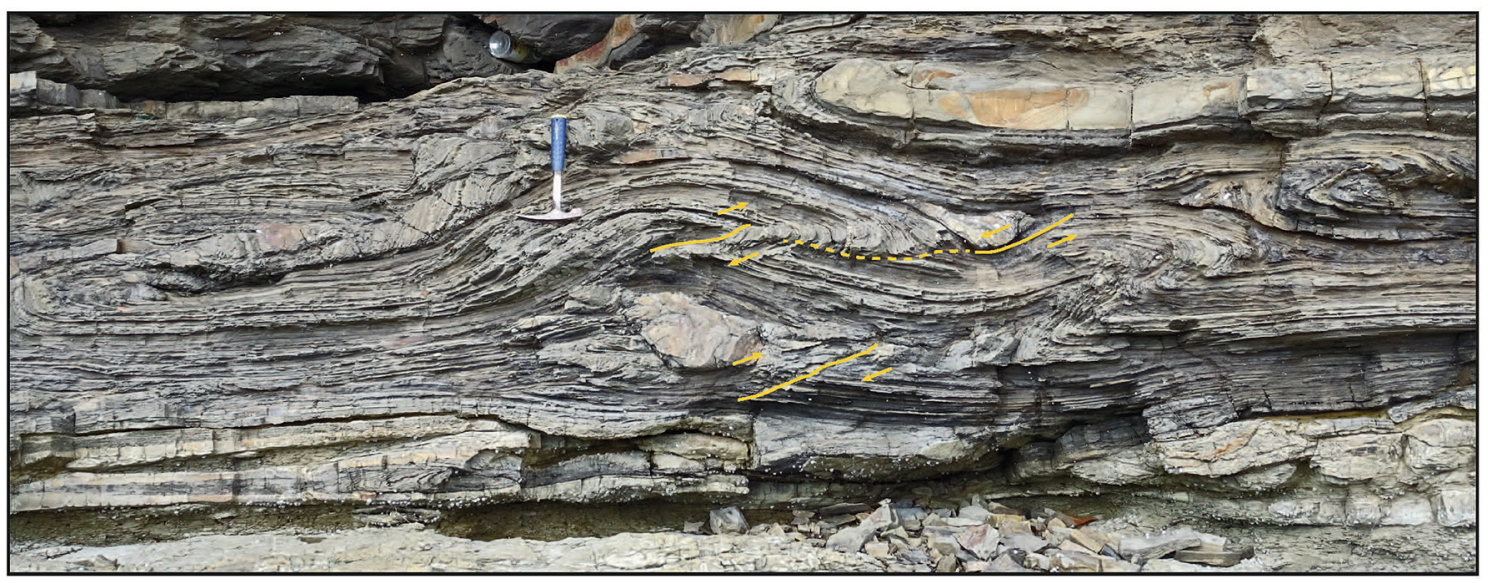

Fig. 12. Faults, commonly up thrusts accompanied by smaller normal faults, are common in the Gyeokpori slumps. Location: middle part of D1 in the Dakibong section 

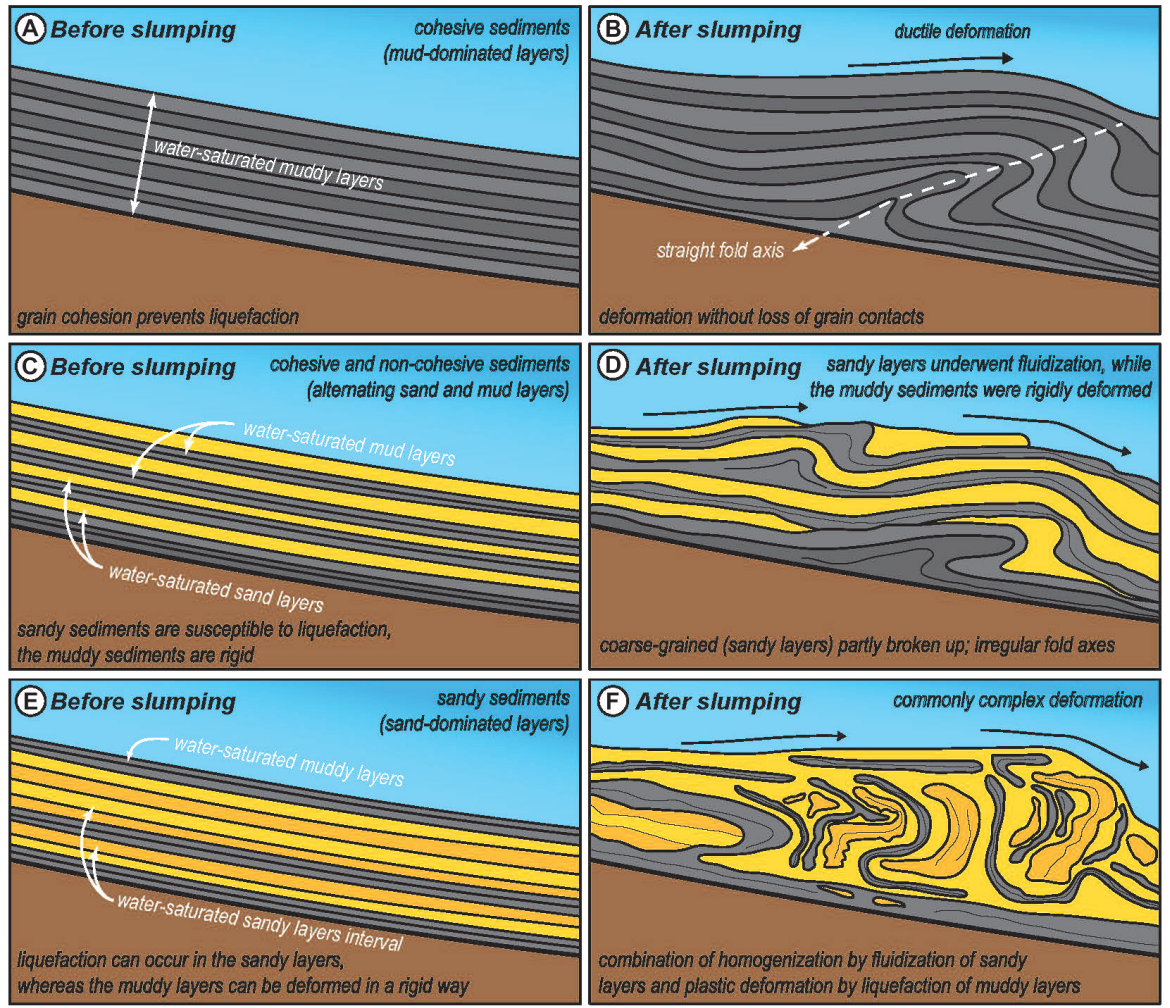

Fig. 13. Schematic 2-D model of the relationship between the dominant grain-sized distribution and the type of slumping. A-B - Slumping of mud-dominated deposits; C-D - Slumping of sediment with mud/sand alternations; E-F Slumping of sand-dominated deposits

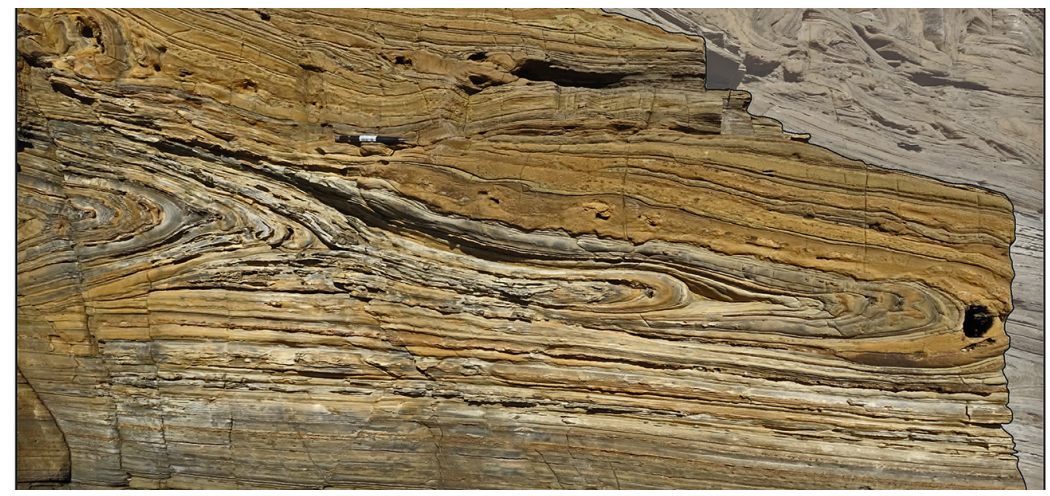

Fig. 14. The fold axes of the slumps are almost exclusively parallel or sub-parallel to the bedding planes

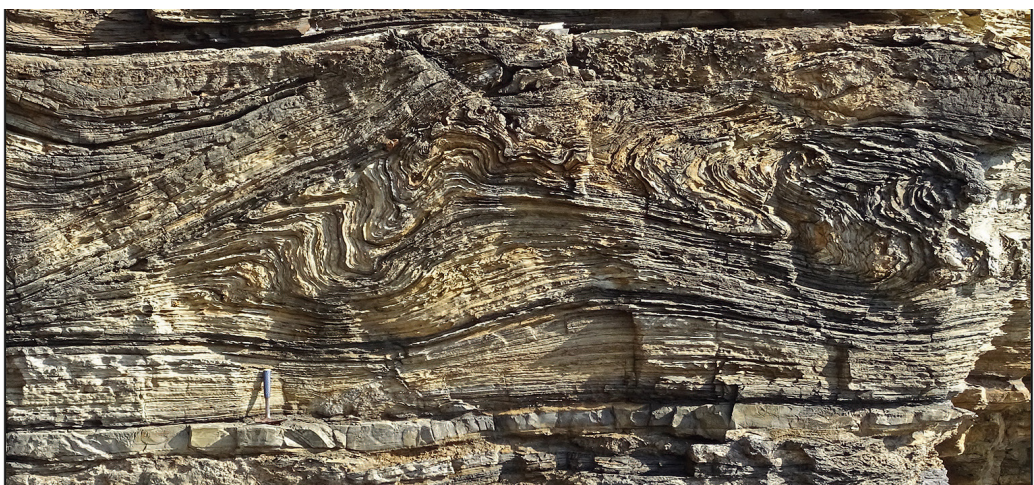

Fig. 15. Slump of cohesive fine-grained sediments, resulting in relatively complex deformations 


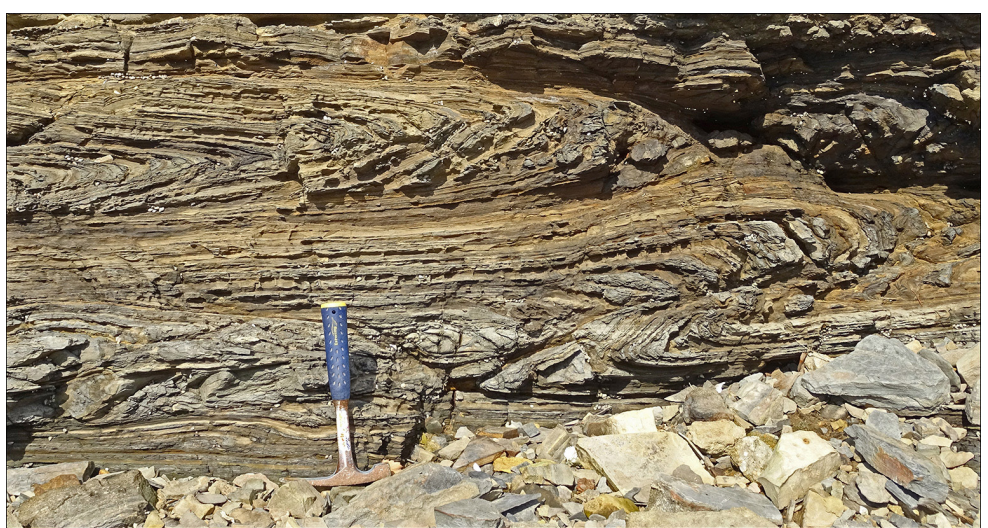

Fig. 16. Slump of non-cohesive sandy sediment, resulting in relatively simple folds complicated by faults

dulating and disrupted laminae are consequently restricted to deposits with intercalations of sand layers (Fig. 7E-F).

It is obvious that the differences in slumping behaviour between the cohesive and the non-cohesive sediments explained above must also be held responsible for the origination, in extreme cases, of the envelope structure.

\section{Discussion}

\subsection{Slumps with a heterolithic composition}

The slumps that are present in the Gyeokpori Formation, commonly as sets of alternating sand and mud couplets (SMc) (Table 1), show that the various lithologies resulted in different types of deformation. The difference in cohesion resulted in non-plastic behaviour of the sands and in plastic behaviour of the muds. Consequently, the muddy layers were systematically bent (Fig. 13A-B) or locally chaotically deformed because of the space problem that is created in the interior of the folds that are created during the rotational movement of the slumping mass, whereas the coarser-grained deposits commonly lost their continuous horizontal lamination or layering due to the development of faults (Fig. 13E-F), depending on their precise place in the slump. The primary lamination and current ripples in the slumped sandy turbidites remained well preserved as a rule.

The difference in plasticity of the various layers did not only affect the type of deformation during slumping, but also the type of movement. Whereas plastic layers could be easily bent, for instance by the rotational movement in the head of the slump, the more brittle sediments, such as gravel layers, were less easily deformed and displaced. In the case of a gravel layer on top of a mud layer, this led to a situation where the mud layer could be bent backwards during the downward flow over the top and along the sides of the gravel mass. As the gravel was much denser than the mud, the gravel mass will probably have had a higher downslope velocity than the mud, thus affecting the bent mud layer in front of it as a bulldozer-like deformation. At the same time, local density inversion may occur sometimes due to the large rock fragments on the mud layer. This must have further facilitated the covering of the gravel mass by the mud layer (Fig. $3)$, thus producing an envelope structure.

\subsection{Could the envelope structure represent an olistostrome?}

The occurrence of conglomerate lenses (Gl) or other 'foreign' material within a sedimentary succession might under conditions of tectonic activity or shocks caused by volcanic eruptions (like in the case of the Gyeokpori Fm.) that lead to slope instability - in principle - also be due to the development of large sediment masses that move downslope as olistostromes or debris flows. Such debris flows or olistostromes tend to be composed of chaotic masses of heterogeneous materials (sometimes in the form of different types of clasts which may be up to several hundreds of metres long, sometimes in the form of irregular patches of sediment with a heterolithic composition). A mass of conglomerate within a succession of mainly sandy and silty turbidites might therefore represent an olistolith forming part of an olistostrome.

The embedded conglomerate lens (Gl) described here does, however, not form part of a larger unit that might be interpreted as an olistostrome. Olistostromes have a catastrophic lower erosional boundary and they generally appear as argillaceous 
bodies with scattered rock fragments (Abbate et al., 1970; Pini et al., 1999).

The conglomerate mass under study cannot represent a single olistolith either, considering the fact that the under- and overlying layer are connected with each other. This can be explained satisfactorily only as a bulldozing effect. Such an effect might in principle - occur when a single olistolith moves down a slope, just before it comes to rest. However, such an olistolith should have reached its final place either by saltation, or by rolling. If saltation would have occurred, a deep imprint should have resulted in the underlying sediment, and such an imprint is absent. If the olistolith would have moved down as a single mass, there would have been no relationship with adjoining sediments, and the mass should may have resulted in a groove cast.

As none of these features that should accompany the downslope movement of an olistostrome or of a single olistolith are present, it must be deduced that the envelope structure cannot feasibly be explained in this way.

\section{Conclusions}

A wide variety of slump types occurs in the Cretaceous Gyeokpori Formation, which accumulated in a lacustrine environment, represented in the area under study by a slope setting. The slumps are composed of sets of turbidite layers of different lithologies. Most sediment involved was mud and sand, but some rare occurrences of gravel are also present. The different types of lithology behaved differently during slumping, mainly because of difference in cohesion, but pore-water content also have played a role.

Gravel masses were not easily deformed during slumping and could become surrounded by folds of the much more cohesive muds. In extreme cases, this could result in a complete isolation of gravel masses inside a folded mud layer. Such a slumping-induced soft-sediment deformation structure is described here for the first time that we is proposed to call it an 'envelope structure'.

\section{Acknowledgements}

The present study was supported through the 'Development of Integrated Geological Information based on Digital Mapping (GP2017-002)' and 'Development of nationwide geoenvironmental maps for HLW geological disposal (GP2017-009)' pro- jects, funded by the Ministry of Science, ICT, and Future Planning of South Korea.

\section{References}

Abbate, E., Bortolotti, V. \& Passerini, P., 1970. Olistostromes and olistoliths. Sedimentary Geology 4, 521557.

Aber, J.S. \& Ber, A. 2007. Glaciotectonism. Developments in Quaternary Science, vol. 6. Elsevier, Amsterdam, $246 \mathrm{pp}$.

Alfaro, P., Moretti, M. \& Soria, J.M., 1997. Soft-sediment deformation structures induced by earthquakes (seismites) in Pliocene lacustrine deposits (Guadix-Baza Basin, central Betic Cordillera). Eclogae Geologicae Helvetiae $90,531-540$.

Allen, J.R.L., 1982. Sedimentary structures: their character and physical basis, Vol. II. Elsevier, Amsterdam, 663 pp.

Alsop, G.I., Marco, S., Weinberger, R. \& Levi, T., 2016. Sedimentary and structural controls on seismogenic slumping within mass transport deposits from the Dead Sea Basin. Sedimentary Geology 344, 71-90.

Bouma, A.H., 1962. Sedimentology of some Flysch Deposits: A Graphic Approach to Facies Interpretation. Elsevier, Amsterdam, $168 \mathrm{pp}$.

Chough, S.K., 2013. Geology and Sedimentology of the Korean Peninsula. Elsevier, Amsterdam, 348 pp.

Chough, S.K. \& Sohn, Y.K., 2010. Tectonic and sedimentary evolution of a Cretaceous continental arc-backarc system in the Korean Peninsula: new view. Earth-Science Reviews 101, 225-249.

Chun S.S. \& Chough S.K., 1992. Depositional sequences from high-concentration turbidity currents, Cretaceous Uhangri Formation (SW Korea). Sedimentary Geology 77, 225-233.

Dehandschutter, B., Vandycke, S., Sintubin, M., Vandenberghe, N. \& Wouters, L., 2005. Brittle fractures and ductile shear bands in argillaceous sediments: inferences from Oligocene Boom Clay (Belgium). Journal of Structural Geology 27, 1095-1112.

Gibert, L., Sanz de Galdeano, C., Alfaro, P., Scott, G. \& Lopez Garrido, A.C., 2005. Seismic induced slump in Early Pleistocene deltaic deposits of the Baza Basin (SE Spain). Sedimentary Geology 179, 279-294.

Gibert, L., Alfaro, P., García-Tortosa, F.J. \& Scott, G., 2011. Superposed deformed beds produced by single earthquakes (Tecopa Basin, California): Insights into paleoseismology. Sedimentary Geology 235, 148-159.

Gladkov, A.S., Lobova, E.U., Deev, E.V., Korzhenkov, A.M., Mazeika, J.V., Abdieva, S.V., Rogozhin, E.A., Rodkin, M.V., Fortuna, A.B., Charimov, T.A. \& Yudakhin, A.S., 2016. Earthquake-induced soft-sediment deformation structures in Late Pleistocene lacustrine deposits of Issyk-Kul lake (Kyrgystan). Sedimentary Geology 344, 112-122.

Gruszka, B. \& Van Loon, A.J., 2011. Genesis of a giant gravity-induced depression (gravifossum) in the Enköping esker, S. Sweden. [In:] Owen, G., Moretti, M. \& Alfaro, P. (Eds): Recognising triggers for soft-sedi- 
ment deformation: current understanding and future directions. Sedimentary Geology 235, 304-313.

Hempton, M.R. \& Dewey, J.F., 1983. Earthquake-induced deformational structures in young lacustrine sediments, East Anatolian Fault, southeast Turkey. Tectonophysics $98, \mathrm{~T} 7-\mathrm{T} 14$.

Jiang, J., Zhong, N., Li, Y., Xu, H., Yang, H. \& Peng, X., 2016. Soft sediment deformation structures in the Lixian lacustrine sediments, eastern Tibetan Plateau and implications for postglacial seismic activity. Sedimentary Geology 344, 123-134.

Kim, S.B., Chough, S.K. \& Chun, S.S., 1995. Bouldery deposits in the lowermost part of the Cretaceous Kyokpori Formation, SW Korea: cohesionless debris flows and debris falls on a steep-gradient delta slope. Sedimentary Geology 98, 97-119.

Kim, S.B., Chough, S.K. \& Chun, S.S., 2003. Tectonic controls on spatio-temporal development of depositional systems and generation of fining-upward basin fills in a strike-slip setting: Kyokpori Formation (Cretaceous), south-west Korea. Sedimentology 50, 639-665.

Ko, K., Park, S. \& Kwon, C.W., 2015. Soft-sediment deformation structures in the Cretaceous Gyeokpori Formation of the Buan area, Korea: Structural characteristics, reconstruction of paleoslope and triggering mechanism of slump. Journal of Geological Society of Korea 51, 545-560 (in Korean, with English abstract).

Ko, K., Kim, S.W., Lee, H.-J., Hwang, I.G., Kim, B.C., Kee, W.-S., Kim, Y.-S. \& Gihm, Y.S., 2017. Soft sediment deformation structures in a lacustrine sedimentary succession induced by volcano-tectonic activities: an example from the Cretaceous Beolgeumri Formation, Wido Volcanics, Korea. Sedimentary Geology 358, 197209.

Koh, H.J., Kwon, C.W., Park, S.I., Park, J. \& Kee, W.S., 2013. Geological report of the Julpo and Wido-Hawangdeungdo sheets $(1: 50,000)$. Korea Institute of Geoscience and Mineral Resources, 81 pp. (in Korean, with English abstract).

Lowe, D.R., 1982. Sediment gravity flows: II. Depositional models with special reference to the deposits of high-density turbidity currents. Journal of Sedimentary Petrology 52, 279-297.

Martinsen, O.J., 1989. Styles of soft- sediment deformation on a Namurian delta slope, western Irish Namurian Basin, Ireland. [In:] M.K.G. Whateley \& K.T. Pickering (Eds): Deltas: sites and traps for fossil fuels. Geological Society, London, Special Publications 41, 167-177.

Mills, P.C., 1983. Genesis and diagnostic value of soft-sediment deformation structures - a review. Sedimentary Geology 35, 83-104.

Moretti, M., Alfaro, P. \& Owen, G., 2016. The environmental significance of soft-sediment deformation structures: key signatures for sedimentary and tectonic processes. Sedimentary Geology 344, 1-4.

Moretti, M. \& Sabato, L., 2007. Recognition of trigger mechanisms for soft-sediment deformation in the Pleistocene lacustrine deposits of the Sant'Arcangelo Basin (southern Italy): seismic shock vs. overloading. Sedimentary Geology 196, 31-45.
Mulder, T. \& Alexander, J., 2001. The physical character of subaqueous sedimentary density currents and their deposits. Sedimentology 48, 269-299.

Nemec, W. \& Steel, R.J., 1984. Alluvial and coastal conglomerates: their significant features and some comments on gravelly mass-flow deposits. [In:] Koster, E.H. \& Steel, R.J. (Eds.): Sedimentology of Gravels and Conglomerates. Memoir of the Canadian Society of Petroleum Geology 10, pp. 1-31.

Neuwerth, R., Suter, F., Guzman, C.A. \& Gorin, G.E., 2006. Soft-sediment deformation in a tectonically active area: The Plio-Pleistocene Zarzal Formation in the Cauca Valley (Western Colombia). Sedimentary Geology 186, 67-88.

Owen, G., 1996. Experimental soft-sediment deformation: structures formed by the liquefaction of unconsolidated sands and some ancient examples. Sedimentology 43, 279-293.

Pini, G.A., 1999. Tectonosomes and olistostromes in the Argille Scagliose of the Northern Apennines, Italy. Geological Society of America Special Paper 335, 1-69.

Porębski. S.J. \& Steel. R.J., 2003. Shelf-margin deltas: their stratigraphic significance and relation to deepwater sands. Earth-Science Reviews 62, 283-326.

Raukas, A., Tirmaa, R., Kaup, E. \& Kimmel, 2001. The age of the Ilumetsa meteorite craters in southeast Estonias. Meteoritics and Planetary Science 36, 1507-1514.

Rodríguez-Pascua, M.A., Calvo, J.P., de Vicente, G. \& Gomez Gras, D., 2000. Seismites in lacustrine sediments of the Prebetic Zone, SE Spain, and their use as indicators of earthquake magnitudes during the Late Miocene. Sedimentary Geology 135, 117-135.

Rygel, M.C., Gibling, M.R. \& Calder, J.H., 2004. Vegetation-induced sedimentary structures from fossil forests in the Pennsylvanian Joggins Formation, Nova Scotia. Sedimentology 51, 531-552.

Sims, J.D., 1973. Earthquake-induced structures in sediments of Van Norman Lake, San Fernando, California. Science 182, 161-163.

Sims, J.D., 1975. Determining earthquake recurrence intervals from deformational structures in young lacustrine sediments. Tectonophysics 29, 141-152.

Talling, P.J., Amy, L.A., Wynn, R.B., Peakall, J. \& Robinson, M., 2004. Beds comprising debrite sandwiched within co-genetic turbidite: origin and widespread occurrence in distal depositional environments. Sedimentology 51, 163-194.

Tanner, L.H. \& Lucas, S.G., 2007. The Moenave Formation: Sedimentologic and stratigraphic context of the Triassic-Jurassic boundary in the Four Corners area, southwestern USA. Palaeogeography, Palaeoclimatology, Palaeoecology 244, 111-125.

Taşgın, C.K. \& Türkmen, I., 2009. Analysis of soft-sediment deformation structures in Neogene fluvio-lacustrine deposits of Çaybağ 1 Formation, Eastern Turkey. Sedimentary Geology 218, 16-30.

Taşgın, C.K., Orhan, H., Türkmen, I. \& Aksoy, E., 2011. Soft-sediment deformation structures in the late Miocene Şelmo Formation around Adiyaman area, Southeastern Turkey. Sedimentary Geology 235, 277-291. 
Tipper, J.C., Sach, V.J. \& Heizmann, E.P.J., 2003. Loading fractures and Liesegang laminae: new sedimentary structures found in the north-western North Alpine Foreland Basin (Oligocene-Miocene, south-west Germany). Sedimentology 50, 791-813.

Uchman, A., Bak, K. \& Rodríguez-Tovar, F.J., 2008. Ichnological record of deep-sea palaeoenvironmental changes around the Oceanic Anoxic Event 2 (Cenomanian-Turonian boundary): an example from the Barnasiówka section, Polish Outer Carpathians. Palaeogeography, Palaeoclimatology, Palaeoecology 262, 61-71.

Van Loon, A.J., 2009. Soft-sediment deformation structures in siliciclastic sediments: an overview. Geologos 15, 3-55.

Van Loon, A.J., 2002. Soft-sediment deformations in the Kleszczów Graben (central Poland). [In:] P.K. Bose, S. Sarkar \& P.G. Ericksson (Eds): Rift basins: sedimentology and palaeontology - Chanda Memorial Issue. Sedimentary Geology 147, 57-70.

Williams, G.E., Gostin, V.A., McKirdy, D.M. \& Preiss, W.V., 2008. The Elatina glaciation, late Cryogenian (Marinoan Epoch), South Australia: Sedimentary facies and palaeoenvironments. Precambrian Research 163, 307-331.
Wynn, J.C., 1998. The day that sands got fire. Scientific American Magazine 279, 64-71.

Yang, R. \& Van Loon, A.J., 2016. Early Cretaceous slumps and turbidites with peculiar soft-sediment deformation structures on Lingshan Island (Qingdao, China) indicating a tensional tectonic regime. Journal of Asian Earth Sciences 129, 206-219.

Yang, R., Van Loon, A.J., Yin, W., Fan, A. \& Han, Z., 2016. Soft-sediment deformation structures in cores from lacustrine slurry deposits of the Late Triassic Yanchang Fm. (central China). Geologos 22, 201-211.

Yang, R., Fan, A., Han, Z. \& Van Loon, A.J., 2017. Lithofacies and origin of the Late Triassic muddy gravity-flow deposits in the Ordos Basin, central China. Marine and Petroleum Geology 85, 194-219.

Zhao, L., Zhou, Y. \& Van Loon, A.J., 2018. Soft-sediment deformation structures induced by rapid sedimentation in Early Cretaceous turbidites, Lingshan Island, eastern China. Canadian Journal of Earth Sciences 55, 118-129.

Manuscript received: 28 April 2019

Revision accepted: 11 July 2019 